medRxiv preprint doi: https://doi.org/10.1101/2021.12.13.21267756; this version posted December 14, 2021. The copyright holder for this preprint (which was not certified by peer review) is the author/funder, who has granted medRxiv a license to display the preprint in perpetuity.

\title{
1 A spectrum of recessiveness among Mendelian disease variants in UK Biobank
}

Alison R. Barton, ${ }^{* 1,2,3}$ Margaux L.A. Hujoel, ${ }^{1,2}$ Ronen E. Mukamel, ${ }^{1,2}$ Maxwell A. Sherman, ${ }^{1,2,4}$ Po-Ru Loh*1,2 $^{* 1}$

1 Division of Genetics, Department of Medicine, Brigham and Women's Hospital and Harvard Medical School, Boston, MA, 02115, USA

93 Bioinformatics and Integrative Genomics Program, Department of Biomedical Informatics, Harvard 10 Medical School, Boston, MA, 02115, USA

114 Computer Science and Artificial Intelligence Laboratory, Massachusetts Institute of Technology, 12 Cambridge, MA, 02139, USA

13 * Correspondence should be addressed to A.R.B. (alisonbarton@g.harvard.edu) or P.-R.L.

14 (poruloh@broadinstitute.org)

\section{Abstract}

Recent work has found increasing evidence of mitigated, incompletely penetrant phenotypes in heterozygous carriers of recessive Mendelian disease variants. We leveraged whole-exome imputation within the full UK Biobank cohort $(N \sim 500 \mathrm{~K})$ to extend such analyses to 3,481 rare variants curated from

ClinVar and OMIM. Testing these variants for association with 57 quantitative traits yielded 103 significant associations involving variants previously implicated in 35 different diseases. Notable examples included a POR missense variant implicated in Antley-Bixler syndrome that associated with a 1.76 (s.e. 0.27 ) cm increase in height, and an $A B C A 3$ missense variant implicated in interstitial lung disease that associated with reduced FEV1/FVC ratio. Association analyses with 1,257 disease traits yielded five additional variant-disease associations. We also observed contrasting levels of recessiveness between two more-common, classical Mendelian diseases. Carriers of cystic fibrosis variants exhibited increased risk of several mitigated disease phenotypes, whereas carriers of spinal muscular atrophy alleles showed no evidence of altered phenotypes. Incomplete penetrance of cystic 
medRxiv preprint doi: https://doi.org/10.1101/2021.12.13.21267756; this version posted December 14, 2021. The copyright holder for this preprint (which was not certified by peer review) is the author/funder, who has granted medRxiv a license to display the preprint in perpetuity. All rights reserved. No reuse allowed without permission.

30 haplotype. Our results show that many disease-associated recessive variants can produce mitigated

31 phenotypes in heterozygous carriers and motivate further work exploring penetrance mechanisms.

Introduction

Since the advent of next generation sequencing, the number of variants identified as contributing to Mendelian disease has grown rapidly ${ }^{1}$. Roughly $20 \%$ of all protein-coding genes in humans have been associated with at least one Mendelian disease ${ }^{2}$. Increasingly, studies of recessive disease variants have begun observing that these variants can sometimes cause mitigated phenotypes in heterozygous carriers, thereby contributing to population variation in complex traits and disease susceptibility ${ }^{3-11}$. However, the rarity of most such variants together with their unavailability in most SNP-array-based genotyping studies has limited attempts to explore this phenomenon at scale. Early work focused on smaller cohorts recruited for specific diseases, such as a series of studies that demonstrated increased risk of male infertility ${ }^{12,13}$, bronchiectasis ${ }^{14-16}$, and asthma ${ }^{15,17}$ among other phenotypes in cystic fibrosis carriers. More recently, larger data sets have enabled extending the breadth of such analyses to more phenotypes $^{4,5}$ and to more recessive disease variants ${ }^{3}$.

With increasing exome sequencing of population biobank cohorts ${ }^{18-20}$, a new opportunity to search for carrier phenotypes in a phenome-wide, exome-wide manner has emerged. Furthermore, biobank data sets present an opportunity to ameliorate ascertainment biases by assessing phenotypes in population cohorts, complementing analyses of patients and their families. Family-based studies have been

51 observed to be susceptible to ascertainment biases that inflate observed effects ${ }^{21}$, while the opposite

52 "healthy volunteer" phenomenon has been observed in biobank cohorts ${ }^{22}$. Genome-wide genotyping

53 and imputation in biobank data sets also provide opportunities to investigate potential genetic modifiers 54 of incompletely penetrant carrier phenotypes ${ }^{23}$. 
medRxiv preprint doi: https://doi.org/10.1101/2021.12.13.21267756; this version posted December 14, 2021. The copyright holder for this preprint (which was not certified by peer review) is the author/funder, who has granted medRxiv a license to display the preprint in perpetuity. All rights reserved. No reuse allowed without permission.

56 Here we leveraged exome-wide imputation within the UK Biobank cohort ${ }^{24}$ to power a broad

57 investigation of quantitative and disease phenotypes amongst carriers of recessive disease variants.

58 Next, we performed a focused analysis of two relatively more common severe recessive Mendelian

59 diseases, using the power afforded by high carrier frequencies to characterize carrier phenotypes or

60 establish a truly recessive pattern of phenotypes. Finally, we considered the molecular mechanisms

61 underlying incomplete penetrance observed amongst carriers, evaluating a previously proposed model

62 of modified penetrance ${ }^{23}$.

\section{Subjects and methods}

\section{Imputed carriers of recessive Mendelian disease variants in UK Biobank}

67 We previously used the first tranche of whole exome sequencing data released by the UK Biobank

$68(N=49,960)^{18}$ to impute coding variants into SNP-array data available for $N=487,409$ participants in the

69 full UK Biobank cohort ${ }^{25}$, achieving accurate imputation of rare variant genotypes at minor allele

70 frequencies (MAF) down to $\sim 0.00005^{24}$. Here, we analyzed a subset of imputed variants that were

71 annotated in $\mathrm{ClinVar}^{26}$ as "pathogenic" or "likely pathogenic" for diseases annotated in OMIM² as

72 "autosomal recessive". We further restricted to rare variants (MAF < 0.01) with a minimum MAF of

730.00001 and estimated imputation accuracy of $R^{2}>0.5$, leaving 3,481 variants for analysis.

\section{Association tests with quantitative traits}

76 We tested imputed genotype dosages for association with 57 quantitative traits using linear mixed

77 models implemented in BOLT-LMM v2.3.4. These traits included the 54 quantitative traits we previously

78 analyzed ${ }^{24}$ and three additional traits (skin pigmentation, tanning ability, and hair color). We performed

79 quantitative trait association analyses on $N=459,327$ UK Biobank participants who reported European 
medRxiv preprint doi: https://doi.org/10.1101/2021.12.13.21267756; this version posted December 14, 2021. The copyright holder for this preprint (which was not certified by peer review) is the author/funder, who has granted medRxiv a license to display the preprint in perpetuity. All rights reserved. No reuse allowed without permission.

ancestry and had not withdrawn from the study at the time of analysis. We did not attempt to filter homozygotes or compound heterozygotes from these analyses, reasoning that such individuals would account for negligible numbers of carriers of the rare variants we analyzed (both based on allele frequencies and on the "healthy volunteer" ascertainment bias of UK Biobank).

\section{Association tests with binary traits}

We tested the same imputed variants for association with 1,139 binary disease phenotypes curated by UK Biobank. These consisted of the complete set of "first-occurrence" of disease traits in the UK Biobank converted to simple case and control status as well as the set of 8 "algorithmically defined health outcomes" disease categories provided by the UK Biobank. We tested variants for association with binary traits using the BinomiRare test ${ }^{27}$ to obtain $p$-values robust to case-control imbalance while adjusting for age (stratified into five-year tranches) and sex. For computational efficiency, we reimplemented the BinomiRare test and applied a binomial approximation when the number of observed cases among carriers exceeded 100 . We estimated odds ratios as $x w / y z$, where $x, y, z, w$ denote ratios of observed versus expected cases among carriers, cases among noncarriers, controls among carriers, and controls among noncarriers, respectively. We estimated $95 \%$ confidence intervals using a normal approximation, i.e., converting $p$-values to $z$-scores and then taking the $95 \% \mathrm{Cl}$ of the log odds ratio $(\mathrm{OR})$ to be $\log (\mathrm{OR}) \pm 1.96$ * $\log \mathrm{OR} / \mathrm{z}$. We performed association analyses on an unrelated subset of $N=415,291$ UK Biobank participants who reported European ancestry and had not withdrawn from the study ${ }^{28}$.

\section{Analyses of cystic fibrosis carriers}

We identified cystic fibrosis carriers in UK Biobank using SNP-array genotypes for the Phe508del variant and (in auxiliary analyses) the missense SNP rs78655421, excluding participants with a cystic fibrosis report (according to the "first occurrences" data field). We applied the same analysis pipeline as 
medRxiv preprint doi: https://doi.org/10.1101/2021.12.13.21267756; this version posted December 14, 2021. The copyright holder for this preprint (which was not certified by peer review) is the author/funder, who has granted medRxiv a license to display the preprint in perpetuity. All rights reserved. No reuse allowed without permission.

105 above to test for associations with the 1,139 binary traits and applied a significance threshold of FDR < $1065 \%(q$-value $<0.05)$

\section{Analyses of spinal muscular atrophy carriers}

109 We identified spinal muscular atrophy carriers in the UK Biobank $N=200 \mathrm{~K}$ exome sequencing release

110 as individuals with evidence of only one functional copy of SMN1. We estimated the number of

111 functional copies of each of SMN1 and SMN2 based on depth of coverage of exome sequencing reads 112 that mapped uniquely to the exon 7-intron 7 region of each gene (chr5:70,951,800-70,952,600 for 113 SMN1 and chr5:70,076,400-70,077,100 for SMN2 in hg38 coordinates; these regions contain four 114 paralogous sequence variants that distinguish the highly homologous genes and were captured by 115 exome sequencing). This approach accounted for deletions of exons 7-8 that commonly inactivate copies of SMN2 and occasionally $S M N 1^{29}$. We computed exome sequencing read-depth using mosdepth v0.3.1 $1^{30}$ and normalized each sample's read-depth measurements against corresponding measurements from other samples with similar exome-wide sequencing depth profiles using a pipeline we recently described ${ }^{28}$.

121 We analyzed SMA carriers for evidence of changes in three traits related to neuromuscular function: 122 walking speed, hand grip strength (maximum of left- and right-hand measurements), and FEV1 / FVC 123 ratio (a measure of lung function). Using age, age squared, and sex as covariates, we performed linear 124 regressions to test for an association between SMA carrier status and each trait.

\section{Testing a model of modified penetrance in carriers of loss-of-function variants}

127 To further investigate potential molecular mechanisms underlying why some recessive variant carriers 128 display mild phenotypes but others do not, we considered a model of modified penetrance proposed by 129 Castel et al. $(2018)^{23}$. This model proposes that the penetrance of a deleterious variant can be affected 130 by variants on the allele on the homologous chromosome, particularly in the case of common cis- 
medRxiv preprint doi: https://doi.org/10.1101/2021.12.13.21267756; this version posted December 14, 2021. The copyright holder for this preprint (which was not certified by peer review) is the author/funder, who has granted medRxiv a license to display the preprint in perpetuity.

All rights reserved. No reuse allowed without permission.

131 eQTLs that modulate expression of the functional copy of the gene. To evaluate this model, we

132 analyzed heterozygous carriers of relatively common disease variants in two genes, FLG and CFTR.

133 To perform association tests on variants carried on the haplotypes opposite the disease variants, we

134 imputed variants from the Haplotype Reference Consortium panel (r1.1) using Minimac3 v2.0.1 (run on

135 genomic windows including $3 \mathrm{Mb}$ flanks of each gene) and analyzed these variants together with the

136 variants we previously imputed from whole-exome sequencing ${ }^{24}$. Next, we extracted the genotypes for

137 these carriers at variants within $1 \mathrm{Mb}$ up- and downstream of each gene. We then recoded the

138 genotypes for each carrier to be hemizygous for the alleles sitting on the haplotype opposite from the

139 deleterious variant. We performed association tests on these recoded hemizygous variants using the

140 Fisher's exact test implemented in plink (v1.9) ${ }^{31}$ (--fisher-midp) (which could perform this analysis after

141 we recoded the chromosome as "X" and coded all individuals as male). We assessed the power of

142 these analyses to detect associations between common variants on the opposite haplotype using the

143 wp.logistic function in the WebPower R package.

145 Results

\section{Quantitative phenotypes in carriers of recessive disease variants}

148 Testing 3,481 rare recessive disease variants for association with 57 quantitative traits measured in the 149 UK Biobank identified 103 significant $\left(p<2.52 \times 10^{-7}\right.$; Bonferroni-corrected) variant-trait associations

150 (Fig. 1 and Table S1). These associations involved variants reported to be pathogenic for 35 distinct

151 recessive diseases. For many of these diseases (19/35 diseases), carriers exhibited significant

152 deviations in multiple quantitative traits. Some of these multiple associations partly reflected correlated

153 measurements of blood, lipid, or pigmentation traits, such as associations between a variant believed to

154 cause Bernard-Soulier syndrome type C (a recessive bleeding disorder) and mean platelet volume

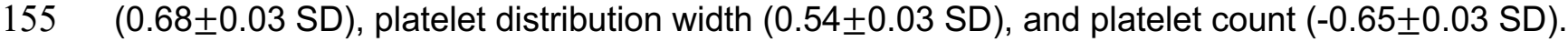


medRxiv preprint doi: https://doi.org/10.1101/2021.12.13.21267756; this version posted December 14, 2021. The copyright holder for this preprint (which was not certified by peer review) is the author/funder, who has granted medRxiv a license to display the preprint in perpetuity. All rights reserved. No reuse allowed without permission.

156 However, others pointed to distinct manifestations of pleiotropy such as associations of a variant for

157 McArdle disease (a recessive glycogen storage disorder that interferes with muscle function) with both 158 increased urate levels $(0.15 \pm 0.02 \mathrm{SD})$ and increased waist-hip ratio $(0.10 \pm 0.02 \mathrm{SD})$.

160 For some of the diseases, carriers exhibited traits that might be expected based on the known 161 biological mechanisms of the disease, supporting the validity of our analytical approach. For example, 162 when considering Mendelian disorders where the production of a particular protein or compound is 163 altered, one might expect a carrier to have reduced levels of that same molecule. We observed this 164 phenomenon with infantile hypophosphatasia, which is defined by errors in alkaline phosphatase ${ }^{32}$. In 165 UK Biobank, carriers of several variants in the ALPL gene reported as pathogenic for recessive hypophosphatasia exhibited decreased alkaline phosphatase (ranging from $-2.63 \pm 0.20$ SD to $0.71 \pm 0.12 \mathrm{SD}$ ) and increased phosphate, as might be expected. Another example involved two variants in ANGPTL3 that have been implicated in hypobetalipoproteinemia 2, a recessive disorder in which individuals experience low levels of several lipid biomarkers ${ }^{33}$. Carriers showed decreases in apolipoprotein A levels (-0.56 \pm 0.04 SD; $-0.63 \pm 0.07$ SD), cholesterol levels $(-0.52 \pm 0.04$ SD; -

$1710.52 \pm 0.07 \mathrm{SD})$, and triglyceride levels (-0.67 $\pm 0.04 \mathrm{SD} ;-0.52 \pm 0.07 \mathrm{SD})$.

173 Other diseases with more complex biological mechanisms yielded less straightforward carrier 174 phenotypes. Here we highlight three such examples. First, a missense variant in POR implicated in 175 Antley-Bixler syndrome ${ }^{34}$, a recessive skeletal disorder in which bones fuse prematurely, associated 176 with a $0.27 \pm 0.04$ SD increase in height (i.e., $1.76 \pm 0.27 \mathrm{~cm}$ ). Second, a frameshift variant in 177 ADAMTSL4 implicated in ectopia lentis 2, a recessive disorder of the fibers in the eyes that can lead to 178 vision problems, associated with a $0.13 \pm 0.02 \mathrm{SD}(0.84 \pm 0.12 \mathrm{~cm})$ decrease in height. Decreased height 179 has been observed in patients with ectopia lentis 2, but the mechanism by which ADAMTSL4 causes 180 this change has not been extensively examined ${ }^{35}$. Third, a missense variant in $A B C A 3$ implicated in 
medRxiv preprint doi: https://doi.org/10.1101/2021.12.13.21267756; this version posted December 14, 2021. The copyright holder for this preprint (which was not certified by peer review) is the author/funder, who has granted medRxiv a license to display the preprint in perpetuity. All rights reserved. No reuse allowed without permission.

181 pulmonary surfactant metabolism dysfunction 3, a recessive interstitial lung disease caused by

182 disruptions in the surface tension of lung surfactant ${ }^{36}$, associated with a $0.12 \pm 0.01$ SD decrease in

183 FEV1/FVC ratio, a measure of lung function. These examples add to the growing body of evidence that 184 rare variants that cause severe disease in homozygotes or compound heterozygotes can often produce 185 mild, subclinical phenotypes in heterozygous carriers ${ }^{3,4}$.

\section{Disease phenotypes in heterozygous carriers of recessive variants}

188 We next tested the same set of 3,481 rare recessive disease variants for association with 1,139 binary 189 traits in UK Biobank, identifying five associations that reached significance $\left(p<1.26 \times 10^{-8}\right.$; Bonferroni190 corrected) (Table 1). As with the quantitative traits, some associations were expected from previous 191 literature. Carriers of a frameshift variant in $H B B$ exhibited increased risk of thalassemia ${ }^{37}$, and carriers 192 of a stop gain variant in COL4A4 implicated in Alport syndrome 2, a recessive disorder that involves 193 kidney dysfunction, exhibited increased risk of hematuria $(\mathrm{OR}=10.5 ; 95 \% \mathrm{Cl}, 5.2-21.2)^{38,39}$, as we and 194 others have recently reported ${ }^{24,40,41}$. Carriers of a missense variant in TYR (tyrosinase) implicated in recessive oculocutaneous albinism type IA exhibited increased risk of disorders of aromatic amino-acid metabolism $(\mathrm{OR}=63.3 ; 95 \% \mathrm{Cl}, 16.3-245.1)^{42}$. A missense variant in TG (thyroglobulin) implicated in

197 recessive thyroid dyshormonogenesis 3 increased risk of hypothyroidism in carriers $(\mathrm{OR}=2.20 ; 95 \% \mathrm{Cl}$, $198 \quad 1.68-2.88)^{43,44}$

A more intriguing association involved a splice donor variant in IFT140 previously implicated in 201 recessive short-rib thoracic dysplasia 9 and retinitis pigmentosa 80 , often with accompanying renal 202 disease ${ }^{45,46}$. Carriers of this variant exhibited increased risk of cystic kidney disease $(\mathrm{OR}=18.4 ; 95 \% \mathrm{Cl}$, 203 8.5-40.1), corroborating recent findings from analyses of directly-sequenced individuals and imputation 204 using the TOPMed reference panel ${ }^{47,48}$. Loss-of-function of both copies of IFT140 appears to be 205 inviable based on murine studies ${ }^{49}$, such that this canonical splice variant has been observed in cases 206 of recessive disease only in compound heterozygotes with partial function of the other copy of the 
medRxiv preprint doi: https://doi.org/10.1101/2021.12.13.21267756; this version posted December 14, 2021. The copyright holder for this preprint (which was not certified by peer review) is the author/funder, who has granted medRxiv a license to display the preprint in perpetuity.

All rights reserved. No reuse allowed without permission.

207 gene ${ }^{50}$. While retinitis pigmentosa 80 primarily manifests in visual symptoms and recessive short-rib 208 thoracic dysplasia 9 in skeletal symptoms, IFT140 encodes a protein related to cilia function that also is 209 expressed in the kidney, and renal symptoms have been noted in both diseases. The observed 210 association between carriers of the splice variant and cystic kidney disease suggests partial 211 haploinsufficiency of IFT140 in its role in the kidney.

\section{Contrasting recessiveness of cystic fibrosis and spinal muscular atrophy}

214 In light of the diversity of autosomal recessive Mendelian diseases for which we observed mitigated 215 phenotypes in carriers, we decided to more closely investigate two relatively common recessive 216 Mendelian diseases to ask whether mitigated phenotypes were a ubiquitous feature of recessive disease carriers. To do so, we identified diseases with sufficiently high carrier frequencies in UK Biobank that we would be well-powered to identify mitigated carrier phenotypes or lack thereof. The two diseases we identified based on these criteria were cystic fibrosis (CF) and spinal muscular atrophy 220 (SMA).

Previous studies have identified mitigated phenotypes in carriers of cystic fibrosis variants related to phenotypic manifestations of the disease ${ }^{4,5}$. To further explore the extent of this phenomenon utilizing the deep phenotyping of UK Biobank, we tested our full set of quantitative and binary traits for associations with carriers of the most common CF mutation, CFTR Phe508del (MAF=1.6\%), which was directly genotyped by UK Biobank SNP-arrays. Carriers of this variant showed significant associations ( $q$-value $<0.05)$ with asthma $(\mathrm{OR}=1.12 ; 95 \% \mathrm{Cl}, 1.06-1.17)$, aspergillosis $(\mathrm{OR}=2.60 ; 95 \% \mathrm{Cl}, 1.63-4.13)$, bronchiectasis (OR=1.40; 95\% Cl,1.20-1.61), and duodenal ulcer (OR=1.30; 95\% Cl,1.15-1.45) (Fig. 229 2a and Table S2). Four additional associations reached significance at a relaxed FDR threshold of 230 10\%: COPD (OR=1.17; 95\% Cl 1.07-1.27), cholelithiasis (OR=1.13; 95\% Cl 1.06-1.22), male infertility $231(\mathrm{OR}=2.10 ; 95 \% \mathrm{Cl}, 1.40-3.15)$, and other prostate disorders (OR=1.39; 95\% Cl 1.15-1.67) (Table S2). 
medRxiv preprint doi: https://doi.org/10.1101/2021.12.13.21267756; this version posted December 14, 2021. The copyright holder for this preprint (which was not certified by peer review) is the author/funder, who has granted medRxiv a license to display the preprint in perpetuity. All rights reserved. No reuse allowed without permission.

232 We also tested carriers of the next most common cystic fibrosis mutation, CFTR Arg117His

233 (MAF=0.2\% in UK Biobank) but concluded that power was insufficient (Table S2).

235 The odds ratios we calculated for carriers of Phe508del, while significant, were much smaller than

236 those recently reported in an analysis of CF carriers ascertained from a database of insurance claims

237 from individuals who had been tested for carrier status ${ }^{4}$ (Fig. S1). Furthermore, several reported

238 associations did not replicate in our analysis of UK Biobank. For example, whereas the claims analysis

239 showed a strong association between carrier status and short stature ${ }^{4}$, we did not observe an

240 association between Phe508del carrier status and height in UK Biobank despite ample power (effect

241 size $=-0.000 \pm 0.006 \mathrm{SD})$. The odds ratios we computed were more consistent with those reported by

242 Çolak et al. (2020) using Phe508del genotyping in the Copenhagen General Population Study ${ }^{5}$. These

243 results underscore the importance of understanding issues of ascertainment bias when studying

244 penetrance in population studies ${ }^{51-53}$

In contrast to CF, potential phenotypes of SMA carriers have not (to our knowledge) previously been

explored, in part because of the difficulty of genotyping SMA carrier mutations, most of which arise from structural variation at the SMN1-SMN2 locus ${ }^{29,54}$. SMA is usually caused by loss-of-function mutations in both copies of the SMN1 gene, with disease severity then determined by the number of functional copies of the paralogous SMN2 gene. The availability of whole-exome sequencing (WES) data for $N \sim 200 K$ UK Biobank participants ${ }^{19}$ enabled us to estimate the number of functional copies of SMN1 252 and SMN2 in each sequenced sample from WES depth-of-coverage (Fig. 2b). We ascertained 3,462 253 SMA carriers (i.e., individuals likely to carry only one functional copy of SMN1) in this way from the set 254 whole-exome sequenced individuals of European-ancestry $(N=187,720)$. Interestingly, we found no 255 significant associations between SMA carrier status and potential manifestations of muscle weakness 256 walking speed, grip strength, and FEV1/FVC ratio (Fig. 2c) - even when stratifying for SMN2 copy 257 number (Table S3). These results suggest that SMA is a truly recessive disease in which muscle 
medRxiv preprint doi: https://doi.org/10.1101/2021.12.13.21267756; this version posted December 14, 2021. The copyright holder for this preprint (which was not certified by peer review) is the author/funder, who has granted medRxiv a license to display the preprint in perpetuity. All rights reserved. No reuse allowed without permission.

weakness phenotypes only manifest in individuals who carry two SMN1 alleles inactivated by loss-offunction variants.

\section{Testing a model of modified penetrance}

In all the instances in which we observed mitigated phenotypes in carriers of recessive disease variants, the associated phenotypes exhibited variable penetrance in heterozygotes. We therefore sought to explore the possible molecular mechanisms underlying this incomplete penetrance.

Castel et al. (2018) previously proposed a model of modified penetrance in which the haplotype arrangement of loss-of-function and expression-modifying variants in an individual might affect overall phenotype (Fig. 3a) $)^{23}$. In this model, the phenotypic impact of a deleterious variant inactivating one copy of a gene is mediated by the amount of expression of the functional copy (on the opposite haplotype), such that a common cis-eQTL influencing expression of the functional allele can influence the severity of the phenotype. Explicitly, if the cis-eQTL increases expression of the functional, wildtype protein, this could partially ameliorate the loss of the other copy; in contrast, if the cis-eQTL decreases expression of the functional copy, one might expect the carrier to have a more severe phenotype.

To explore this hypothesis, we considered two genes, FLG and CFTR, in which variants known to cause both recessive disease and produce mitigated phenotypes in carriers are sufficiently common to power analysis. Loss-of-function variants in FLG are known to cause ichthyosis vulgaris in homozygotes or compound heterozygotes, and carrier status has been associated with asthma and atopic dermatitis $^{55,56}$. In UK Biobank, $10.3 \%$ of participants carried a loss-of-function variant in FLG that was associated with asthma or atopic dermatitis in heterozygotes. As discussed in the previous section, mutations in CFTR are responsible for cystic fibrosis, as well as several mitigated phenotypes in carriers. Approximately $3.1 \%$ of individuals in the UK Biobank are carriers for the Phe508del mutation in CFTR that we considered for this analysis. 
medRxiv preprint doi: https://doi.org/10.1101/2021.12.13.21267756; this version posted December 14, 2021. The copyright holder for this preprint (which was not certified by peer review) is the author/funder, who has granted medRxiv a license to display the preprint in perpetuity. All rights reserved. No reuse allowed without permission.

285 To determine whether variants on the opposite (putatively functional) haplotype in carriers might affect 286 their susceptibility to mitigated phenotypes, we restricted our analysis just to carriers of these

287 deleterious variants (Fig. 3b). For each nearby variant at each locus, we then ran an association test 288 between opposite-haplotype genotypes and mitigated phenotypes. No tested variant at either locus 289 significantly associated with phenotype (Fig. 3c). Given that we were well-powered to detect common 290 variant associations with an odds ratio $>1.2$ in both scenarios (Fig. 3d), these results suggest that the 291 modified penetrance model is unlikely to underlie incomplete penetrance of these carrier phenotypes.

\section{Discussion}

Our results demonstrate that for a wide range of Mendelian diseases, variants traditionally considered to be recessive can cause milder phenotypes in heterozygous carriers. We also observed that entirely recessive effects do exist: heterozygous carriers for spinal muscular atrophy exhibited no evidence of even a subtle effect on phenotypes related to muscle strength. These observations suggest a spectrum of recessiveness that is now becoming visible in very large population cohorts.

301 Our study did have several limitations. First, even with the large sample size provided by exome 302 sequencing in UK Biobank, we still lacked power to assess potential effects of many very rare variants 303 that are known to cause Mendelian recessive diseases. Second, our examination of potential 304 interactions between variants on opposite haplotypes was even more power-constrained, such that we 305 could only assess this model for two diseases involving common variants. Third, the effects we 306 estimated are likely to be influenced by the "healthy volunteer" ascertainment bias observed in analyses 307 of population biobank cohorts ${ }^{22}$. 
medRxiv preprint doi: https://doi.org/10.1101/2021.12.13.21267756; this version posted December 14, 2021. The copyright holder for this preprint (which was not certified by peer review) is the author/funder, who has granted medRxiv a license to display the preprint in perpetuity. All rights reserved. No reuse allowed without permission.

309 As even larger, well-phenotyped cohorts with whole-exome or whole-genome sequencing become

310 available, our ability to determine the extent of mild carrier phenotypes will increase. More

311 comprehensive phenome-wide and genome-wide studies will allow for an assessment of how common

312 the phenomenon of incomplete recessivity is amongst severe Mendelian diseases and the spectrum of

313 phenotypes that can manifest. Moreover, the higher power afforded by extremely large studies will also

314 enable more extensive exploration of potential interactions between variants that could help to explain

315 incomplete penetrance and shed light on the molecular mechanisms that underlie mitigated

316 phenotypes.

317 
medRxiv preprint doi: https://doi.org/10.1101/2021.12.13.21267756; this version posted December 14, 2021. The copyright holder for this preprint (which was not certified by peer review) is the author/funder, who has granted medRxiv a license to display the preprint in perpetuity. All rights reserved. No reuse allowed without permission.

318 Supplemental data include one figure and three tables.

\section{Acknowledgments}

321 We thank A. Gusev, A. Price and S. Sunyaev for helpful discussions. This research was conducted 322 using the UK Biobank Resource under application no. 10438. A.R.B. was supported by US NIH grant 323 T32 HG229516 and fellowship F31 HL154537. M.L.A.H. was supported by US NIH fellowship F32 324 HL160061. M.A.S. was supported by the MIT John W. Jarve (1978) Seed Fund for Science Innovation 325 and US NIH fellowship F31 MH124393. R.E.M. was supported by US NIH grant K25 HL150334 and 326 NSF grant DMS-1939015. P.-R.L. was supported by US NIH grant DP2 ES030554, a Burroughs 327 Wellcome Fund Career Award at the Scientific Interfaces, the Next Generation Fund at the Broad 328 Institute of MIT and Harvard, and a Sloan Research Fellowship. The funders had no role in study 329 design, data collection and analysis, decision to publish or preparation of the manuscript.

330 Computational analyses were performed on the $\mathrm{O} 2$ High Performance Compute Cluster, supported by

331 the Research Computing Group, at Harvard Medical School (http://rc.hms.harvard.edu).

\section{Declaration of interests}

334 The authors declare no competing interests.

Data and code availability

337 Access to the UK Biobank Resource is available by application (http://www.ukbiobank.ac.uk/). BOLT338 LMM (v2.3.4) is available at https://data.broadinstitute.org/alkesgroup/BOLT-LMM/. mosdepth (v0.3.1) 339 is available at https://github.com/brentp/mosdepth. Minimac4 (v.1.0.1) is available at 340 https://genome.sph.umich.edu/wiki/Minimac4. plink (v1.9) is available from https://www.cog341 genomics.org/plink1.9/. 


\section{Web resources}

ClinVar, https://www.ncbi.nlm.nih.gov/clinvar/

OMIM, https://omim.org/

\section{References}

1. Bamshad, M.J., Ng, S.B., Bigham, A.W., Tabor, H.K., Emond, M.J., Nickerson, D.A., and Shendure, J. (2011). Exome sequencing as a tool for Mendelian disease gene discovery. Nat. Rev. Genet. 12, 745351755.

2. Hamosh, A., Amberger, J.S., Bocchini, C., Scott, A.F., and Rasmussen, S.A. (2021). Online Mendelian Inheritance in Man (OMIM®): Victor McKusick's magnum opus. Am. J. Med. Genet. A $185,3259-3265$.

3. Wright, C.F., West, B., Tuke, M., Jones, S.E., Patel, K., Laver, T.W., Beaumont, R.N., Tyrrell, J., Wood, A.R., Frayling, T.M., et al. (2019). Assessing the Pathogenicity, Penetrance, and Expressivity of Putative Disease-Causing Variants in a Population Setting. Am. J. Hum. Genet. 104, 275-286.

4. Miller, A.C., Comellas, A.P., Hornick, D.B., Stoltz, D.A., Cavanaugh, J.E., Gerke, A.K., Welsh, M.J., Zabner, J., and Polgreen, P.M. (2020). Cystic fibrosis carriers are at increased risk for a wide range of cystic fibrosis-related conditions. Proc. Natl. Acad. Sci. U.S.A. 117, 1621-1627.

361 5. Çolak, Y., Nordestgaard, B.G., and Afzal, S. (2020). Morbidity and mortality in carriers of the cystic 362 fibrosis mutation CFTR Phe508del in the general population. Eur. Respir. J. 56, 2000558. Jüppner, H. (2010). Long-term clinical outcome and carrier phenotype in autosomal recessive hypophosphatemia caused by a novel DMP1 mutation. J. Bone Miner. Res. 25, 2165-2174.

7. Dagher, H., Buzza, M., Colville, D., Jones, C., Powell, H., Fassett, R., Wilson, D., Agar, J., and Savige, J. (2001). A comparison of the clinical, histopathologic, and ultrastructural phenotypes in carriers of X-linked and autosomal recessive Alport's syndrome. Am. J. Kidney Dis. 38, 1217-1228.

8. Watts, J.A., Morley, M., Burdick, J.T., Fiori, J.L., Ewens, W.J., Spielman, R.S., and Cheung, V.G. (2002). Gene expression phenotype in heterozygous carriers of ataxia telangiectasia. Am. J. Hum. Genet. 71, 791-800.

9. Sidransky, E., Nalls, M.A., Aasly, J.O., Aharon-Peretz, J., Annesi, G., Barbosa, E.R., Bar-Shira, A., Berg, D., Bras, J., Brice, A., et al. (2009). Multicenter analysis of glucocerebrosidase mutations in Parkinson's disease. N. Engl. J. Med. 361, 1651-1661.

10. Vieira, S.R.L., and Morris, H.R. (2021). Neurodegenerative Disease Risk in Carriers of Autosomal Recessive Disease. Front. Neurol. 12, 679927-679927. 
medRxiv preprint doi: https://doi.org/10.1101/2021.12.13.21267756; this version posted December 14, 2021. The copyright holder for this preprint (which was not certified by peer review) is the author/funder, who has granted medRxiv a license to display the preprint in perpetuity. All rights reserved. No reuse allowed without permission.

11. Perez, Y., Wormser, O., Sadaka, Y., Birk, R., Narkis, G., and Birk, O.S. (2017). A Rare Variant in PGAP2 Causes Autosomal Recessive Hyperphosphatasia with Mental Retardation Syndrome, with a Mild Phenotype in Heterozygous Carriers. Biomed. Res. Int. 2017, 3470234.

12. Chillón, M., Casals, T., Mercier, B., Bassas, L., Lissens, W., Silber, S., Romey, M.-C., RuizRomero, J., Verlingue, C., Claustres, M., et al. (1995). Mutations in the Cystic Fibrosis Gene in Patients with Congenital Absence of the Vas Deferens. N. Engl. J. Med. 332, 1475-1480.

13. Yu, J., Chen, Z., Ni, Y., and Li, Z. (2012). CFTR mutations in men with congenital bilateral absence of the vas deferens (CBAVD): a systemic review and meta-analysis. Hum. Reprod. 27, 25-35.

14. Girodon, E., Cazeneuve, C., Lebargy, F., Chinet, T., Costes, B., Ghanem, N., Martin, J., Lemay, S., Scheid, P., Housset, B., et al. (1997). CFTR gene mutations in adults with disseminated bronchiectasis. Eur. J. Hum. Genet. 5, 149-155.

15. Tzetis, M., Efthymiadou, A., Strofalis, S., Psychou, P., Dimakou, A., Pouliou, E., Doudounakis, S., and Kanavakis, E. (2001). CFTR gene mutations - including three novel nucleotide substitutions - and haplotype background in patients with asthma, disseminated bronchiectasis and chronic obstructive pulmonary disease. Hum. Genet. 108, 216-221.

16. Casals, T., De-Gracia, J., Gallego, M., Dorca, J., Rodríguez-Sanchón, B., Ramos, M., Giménez, J., Cisteró-Bahima, A., Olveira, C., and Estivill, X. (2004). Bronchiectasis in adult patients: an expression of heterozygosity for CFTR gene mutations? Clin. Genet. 65, 490-495.

17. Nielsen, A.O., Qayum, S., Bouchelouche, P.N., Laursen, L.C., Dahl, R., and Dahl, M. (2016). Risk of asthma in heterozygous carriers for cystic fibrosis: A meta-analysis. J. Cyst. Fibros. 15, 563-567.

18. Van Hout, C.V., Tachmazidou, I., Backman, J.D., Hoffman, J.D., Liu, D., Pandey, A.K., GonzagaJauregui, C., Khalid, S., Ye, B., Banerjee, N., et al. (2020). Exome sequencing and characterization of 49,960 individuals in the UK Biobank. Nature 586, 749-756.

19. Szustakowski, J.D., Balasubramanian, S., Kvikstad, E., Khalid, S., Bronson, P.G., Sasson, A., Wong, E., Liu, D., Wade Davis, J., Haefliger, C., et al. (2021). Advancing human genetics research and drug discovery through exome sequencing of the UK Biobank. Nat. Genet. 53, 942-948.

20. Backman, J.D., Li, A.H., Marcketta, A., Sun, D., Mbatchou, J., Kessler, M.D., Benner, C., Liu, D., Locke, A.E., Balasubramanian, S., et al. (2021). Exome sequencing and analysis of 454,787 UK Biobank participants. Nature 599, 628-634.

21. Cooper, D.N., Krawczak, M., Polychronakos, C., Tyler-Smith, C., and Kehrer-Sawatzki, H. (2013). Where genotype is not predictive of phenotype: towards an understanding of the molecular basis of reduced penetrance in human inherited disease. Hum. Genet. 132, 1077-1130.

22. Fry, A., Littlejohns, T.J., Sudlow, C., Doherty, N., Adamska, L., Sprosen, T., Collins, R., and Allen, N.E. (2017). Comparison of Sociodemographic and Health-Related Characteristics of UK Biobank Participants With Those of the General Population. Am. J. Epidemiol. 186, 1026-1034. 
23. Castel, S.E., Cervera, A., Mohammadi, P., Aguet, F., Reverter, F., Wolman, A., Guigo, R., Iossifov, I., Vasileva, A., and Lappalainen, T. (2018). Modified penetrance of coding variants by cis-regulatory variation contributes to disease risk. Nat. Genet. 50, 1327-1334.

24. Barton, A.R., Sherman, M.A., Mukamel, R.E., and Loh, P.-R. (2021). Whole-exome imputation within UK Biobank powers rare coding variant association and fine-mapping analyses. Nat. Genet. 53 , $1260-1269$.

25. Bycroft, C., Freeman, C., Petkova, D., Band, G., Elliott, L.T., Sharp, K., Motyer, A., Vukcevic, D., Delaneau, O., O'Connell, J., et al. (2018). The UK Biobank resource with deep phenotyping and genomic data. Nature 562, 203-209.

26. Landrum, M.J., Lee, J.M., Benson, M., Brown, G.R., Chao, C., Chitipiralla, S., Gu, B., Hart, J., Hoffman, D., Jang, W., et al. (2018). ClinVar: improving access to variant interpretations and supporting evidence. Nucleic Acids Res. 46, D1062-D1067.

27. Sofer, T. (2017). BinomiRare: a robust test of the association of a rare-variant with a disease for pooled and meta-analysis, with application to the HCHS/SOL. Genet. Epidemiol. 41, 388-395.

28. Mukamel, R.E., Handsaker, R.E., Sherman, M.A., Barton, A.R., Zheng, Y., McCarroll, S.A., and Loh, P.-R. (2021). Protein-coding repeat polymorphisms strongly shape diverse human phenotypes. Science 373, 1499-1505.

29. Chen, X., Sanchis-Juan, A., French, C.E., Connell, A.J., Delon, I., Kingsbury, Z., Chawla, A., Halpern, A.L., Taft, R.J., Bentley, D.R., et al. (2020). Spinal muscular atrophy diagnosis and carrier screening from genome sequencing data. Genet. Med. 22, 945-953.

30. Brent S. Pedersen, and Quinlan, A.R. (2018). Mosdepth: quick coverage calculation for genomes and exomes. Bioinformatics 34, Pages 867-868.

31. Chang, C.C., Chow, C.C., Tellier, L.C., Vattikuti, S., Purcell, S.M., and Lee, J.J. (2015). Secondgeneration PLINK: rising to the challenge of larger and richer datasets. GigaScience 4, s13742-0150047-0048.

32. Weiss, M.J., Cole, D.E., Ray, K., Whyte, M.P., Lafferty, M.A., Mulivor, R.A., and Harris, H. (1988). A missense mutation in the human liver/bone/kidney alkaline phosphatase gene causing a lethal form of hypophosphatasia. Proc. Natl. Acad. Sci. U.S.A. 85, 7666-7669.

33. Musunuru, K., Pirruccello, J.P., Do, R., Peloso, G.M., Guiducci, C., Sougnez, C., Garimella, K.V., Fisher, S., Abreu, J., Barry, A.J., et al. (2010). Exome Sequencing, ANGPTL3 Mutations, and Familial Combined Hypolipidemia. N. Engl. J. Med. 363, 2220-2227.

34. Flück, C.E., Tajima, T., Pandey, A.V., Arlt, W., Okuhara, K., Verge, C.F., Jabs, E.W., Mendonça, B.B., Fujieda, K., and Miller, W.L. (2004). Mutant P450 oxidoreductase causes disordered steroidogenesis with and without Antley-Bixler syndrome. Nat. Genet. 36, 228-230. 
medRxiv preprint doi: https://doi.org/10.1101/2021.12.13.21267756; this version posted December 14, 2021. The copyright holder for this preprint (which was not certified by peer review) is the author/funder, who has granted medRxiv a license to display the preprint in perpetuity. All rights reserved. No reuse allowed without permission.

35. Neuhann, T.M., Stegerer, A., Riess, A., Blair, E., Martin, T., Wieser, S., Kläs, R., Bouman, A., Kuechler, A., and Rittinger, O. (2015). ADAMTSL4-associated isolated ectopia lentis: Further patients, novel mutations and a detailed phenotype description. Am. J. Med. Genet. A 167, 2376-2381.

36. Shulenin, S., Nogee, L.M., Annilo, T., Wert, S.E., Whitsett, J.A., and Dean, M. (2004). ABCA3 Gene Mutations in Newborns with Fatal Surfactant Deficiency. N. Engl. J. Med. 350, 1296-1303.

37. Taher, A.T., Musallam, K.M., and Cappellini, M.D. (2021). $\beta$-Thalassemias. N. Engl. J. Med. 384, 727-743.

38. Longo, I., Porcedda, P., Mari, F., Giachino, D., Meloni, I., Deplano, C., Brusco, A., Bosio, M., Massella, L., Lavoratti, G., et al. (2002). COL4A3/COL4A4 mutations: From familial hematuria to autosomal-dominant or recessive Alport syndrome. Kidney Int. 61, 1947-1956.

39. Buzza, M., Wang, Y.Y., Dagher, H., Babon, J.J., Cotton, R.G., Powell, H., Dowling, J., and Savige, J. (2001). COL4A4 mutation in thin basement membrane disease previously described in Alport syndrome1. Kidney Int. 60, 480-483.

40. Yang, C., Song, Y., Chen, Z., Yuan, X., Chen, X., Ding, G., Guan, Y., McGrath, M., Song, C., Tong, Y., et al. (2019). A Nonsense Mutation in COL4A4 Gene Causing Isolated Hematuria in Either Heterozygous or Homozygous State. Front. Genet. 10, 628.

41. Sinnott-Armstrong, N., Tanigawa, Y., Amar, D., Mars, N., Benner, C., Aguirre, M., Venkataraman, G.R., Wainberg, M., Ollila, H.M., Kiiskinen, T., et al. (2021). Genetics of 35 blood and urine biomarkers in the UK Biobank. Nat. Genet. 53, 185-194.

42. Grønskov, K., Ek, J., and Brondum-Nielsen, K. (2007). Oculocutaneous albinism. Orphanet J. Rare Dis. 2, 43.

43. Ieiri, T., Cochaux, P., Targovnik, H.M., Suzuki, M., Shimoda, S., Perret, J., and Vassart, G. (1991). A 3' splice site mutation in the thyroglobulin gene responsible for congenital goiter with hypothyroidism. J. Clin. Invest. 88, 1901-1905.

44. Grasberger, H., and Refetoff, S. (2011). Genetic causes of congenital hypothyroidism due to dyshormonogenesis. Curr. Opin. Pediatr. 23, 421-428.

45. Perrault, I., Saunier, S., Hanein, S., Filhol, E., Bizet, A.A., Collins, F., Salih, M.A.M., Gerber, S., Delphin, N., Bigot, K., et al. (2012). Mainzer-Saldino syndrome is a ciliopathy caused by IFT140 mutations. Am. J. Hum. Genet. 90, 864-870.

46. Schmidts, M., Frank, V., Eisenberger, T., al Turki, S., Bizet, A.A., Antony, D., Rix, S., Decker, C., Bachmann, N., Bald, M., et al. (2013). Combined NGS Approaches Identify Mutations in the Intraflagellar Transport Gene IFT140 in Skeletal Ciliopathies with Early Progressive Kidney Disease. Hum. Mutat. 34, 714-724.

47. Taliun, D., Harris, D.N., Kessler, M.D., Carlson, J., Szpiech, Z.A., Torres, R., Taliun, S.A.G., Corvelo, A., Gogarten, S.M., Kang, H.M., et al. (2021). Sequencing of 53,831 diverse genomes from the NHLBI TOPMed Program. Nature 590, 290-299. 
medRxiv preprint doi: https://doi.org/10.1101/2021.12.13.21267756; this version posted December 14, 2021. The copyright holder for this preprint (which was not certified by peer review) is the author/funder, who has granted medRxiv a license to display the preprint in perpetuity. All rights reserved. No reuse allowed without permission.

48. Senum, S.R., Li, Y. (Sabrina) M., Benson, K.A., Joli, G., Olinger, E., Lavu, S., Madsen, C.D., Gregory, A.V., Neatu, R., Kline, T.L., et al. (2021). Monoallelic IFT140 pathogenic variants are an important cause of the autosomal dominant polycystic kidney-spectrum phenotype. Am. J. Hum. Genet.

49. Jonassen, J.A., SanAgustin, J., Baker, S.P., and Pazour, G.J. (2012). Disruption of IFT Complex A Causes Cystic Kidneys without Mitotic Spindle Misorientation. J. Am. Soc. Nephrol. 23, 641-651.

50. Online Mendelian Inheritance in Man, OMIM® (2019). MIM Number 614620. (Baltimore, MD: Johns Hopkins University).

51. Ganguli, M., Lytle, M.E., Reynolds, M.D., and Dodge, H.H. (1998). Random versus volunteer selection for a community-based study. J. Gerontol. A Biol. Sci. Med. Sci. 53, M39-46.

52. Mirshahi, U.L., Colclough, K., Wright, C.F., Wood, A.R., Beaumont, R.N., Tyrrell, J., Laver, T.W., Stahl, R., Golden, A., Goehringer, J.M., et al. (2021). The penetrance of age-related monogenic disease depends on ascertainment context. MedRxiv 2021.06.28.21259641.

53. Forrest, I.S., Chaudhary, K., Vy, H.M.T., Bafna, S., Jordan, D.M., Rocheleau, G., Loos, R.J.F., Cho, J.H., and Do, R. (2021). Ancestrally and Temporally Diverse Analysis of Penetrance of Clinical Variants in 72,434 Individuals. MedRxiv 2021.03.11.21253430.

54. Alías, L., Bernal, S., Fuentes-Prior, P., Barceló, M.J., Also, E., Martínez-Hernández, R., RodríguezAlvarez, F.J., Martín, Y., Aller, E., Grau, E., et al. (2009). Mutation update of spinal muscular atrophy in Spain: molecular characterization of 745 unrelated patients and identification of four novel mutations in the SMN1 gene. Hum. Genet. 125, 29-39.

55. Weidinger, S., O’Sullivan, M., Illig, T., Baurecht, H., Depner, M., Rodriguez, E., Ruether, A., Klopp, N., Vogelberg, C., Weiland, S.K., et al. (2008). Filaggrin mutations, atopic eczema, hay fever, and asthma in children. J. Allergy Clin. Immunol. 121, 1203-1209.e1.

56. Wang, Q., Dhindsa, R.S., Carss, K., Harper, A., Nag, A., Tachmazidou, I., Vitsios, D., Deevi, S.V., Mackay, A., Muthas, D., et al. (2020). Surveying the contribution of rare variants to the genetic architecture of human disease through exome sequencing of 177,882 UK Biobank participants. BioRxiv 2020.12.13.422582. 
medRxiv preprint doi: https://doi.org/10.1101/2021.12.13.21267756; this version posted December 14,2021 . The copyright holder for this preprint (which was not certified by peer review) is the author/funder, who has granted medRxiv a license to display the preprint in perpetuity.

\section{Figures}

511 Figure 1. Carriers of recessive Mendelian disease variants display quantitative phenotypes.

512 Mendelian diseases and their associated genes are listed to the left in each column, and the mean

513 effect size is plotted on the right for each associated quantitative trait in units of standard deviation

514 (error bars, 95\% Cls). Positive-effect variants are shown in red, negative-effect variants in blue, and 515 variants not Bonferroni-significant for one of the displayed traits in gray. Marker shapes correspond to effects on the gene and gene product as reported in ClinVar.

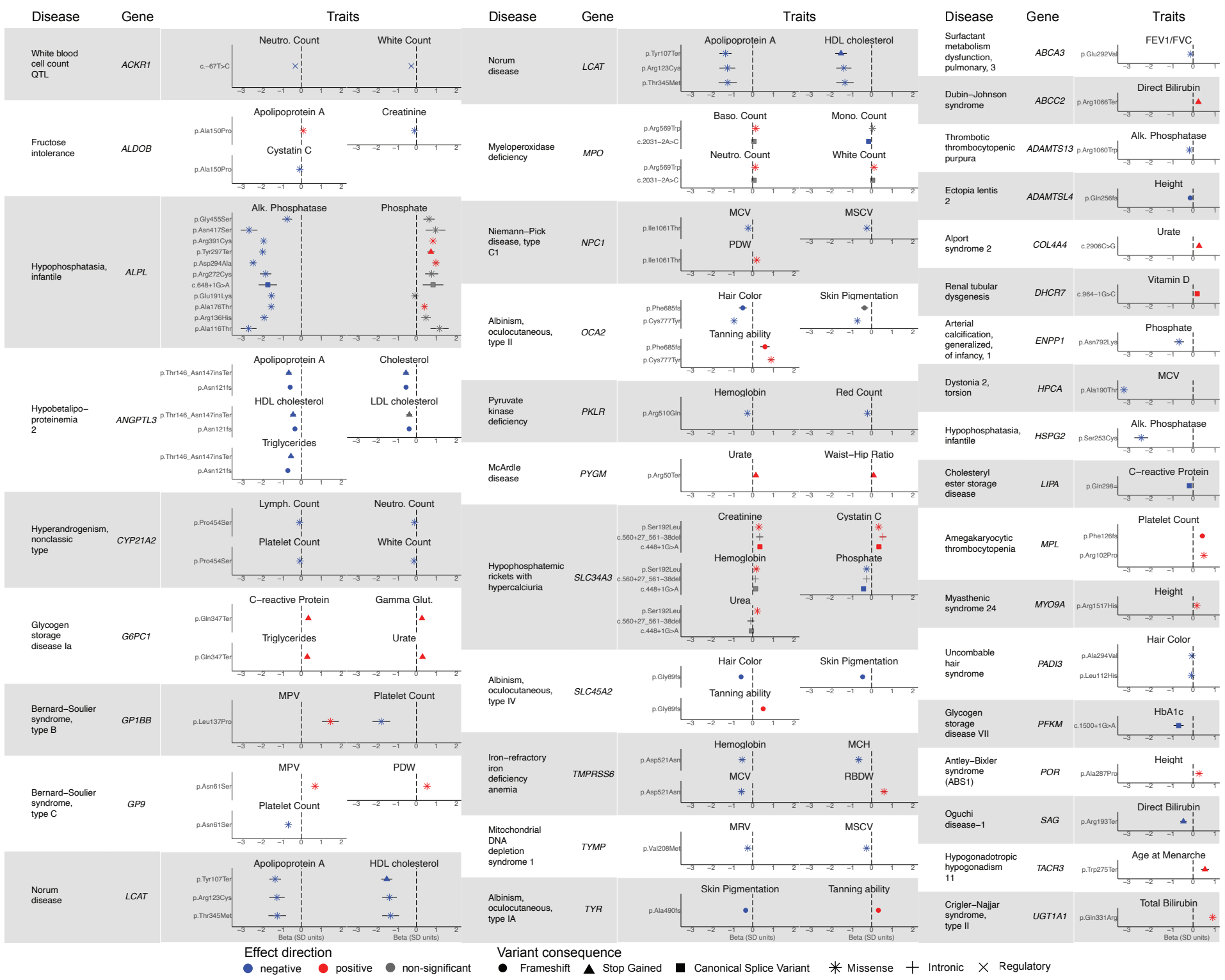


medRxiv preprint doi: https://doi.org/10.1101/2021.12.13.21267756; this version posted December 14, 2021. The copyright holder for this preprint (which was not certified by peer review) is the author/funder, who has granted medRxiv a license to display the preprint in perpetuity.

517 Figure 2. Cystic fibrosis carriers show mitigated phenotypes, but spinal muscular atrophy carriers do not. (a) Carriers with the CFTR Phe508del inframe deletion exhibit increased risk of several mitigated disease phenotypes (data points, odds ratios; error bars, $95 \% \mathrm{Cls}$ ). (b) Genotyping for SMA carrier status using exome sequencing data from the UK Biobank. SMN1 and SMN2 copy numbers were estimated based on sequencing read depth, and SMA carriers (orange) were identified as those individuals estimated to have one functional copy of SMN1 (with a deletion allele on the homologous chromosome). (c) SMN1 deletion carriers did not display evidence of changes in any of three traits related to neuromuscular function (data points, mean values in units of standard deviations; error bars, $95 \% \mathrm{Cls}$ ).
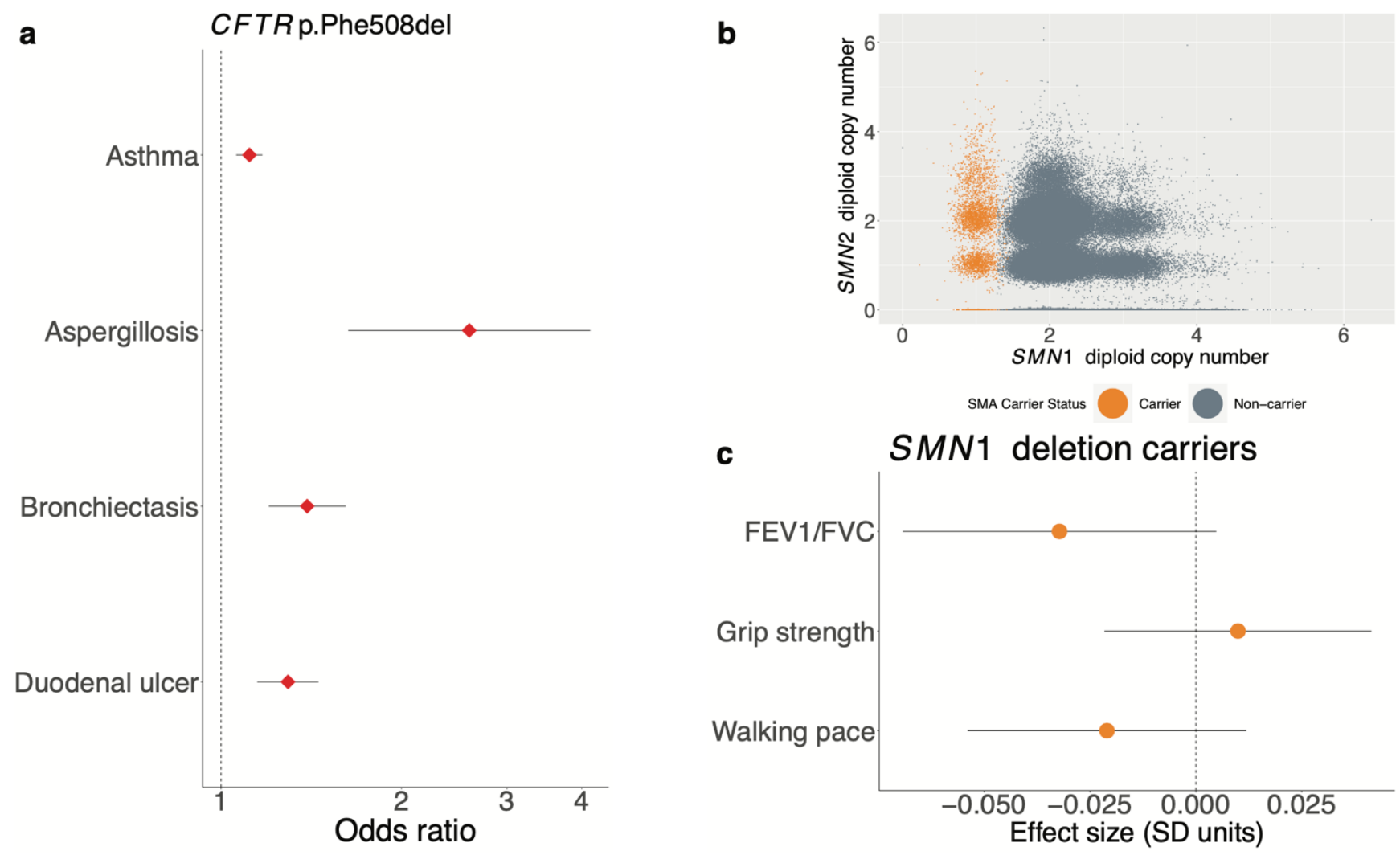
medRxiv preprint doi: https://doi.org/10.1101/2021.12.13.21267756; this version posted December 14, 2021. The copyright holder for this preprint (which was not certified by peer review) is the author/funder, who has granted medRxiv a license to display the preprint in perpetuity.

Figure 3. Common variants on haplotypes opposite recessive alleles in carriers of two Mendelian diseases do not appear to modify penetrance of carrier phenotypes. (a) The "modified penetrance" model of Castel et al. (2018) posits that cis-eQTLs can increase or decrease severity of a deleterious variant by modulating the quantity of functional protein produced by the opposite haplotype. (b) To test this hypothesis, we examined opposite haplotypes (blue chromosomes) in heterozygous carriers of recessive disease variants (orange star on yellow chromosome). We tested variants carried on these opposite haplotypes for association with mitigated phenotypes observed in carriers. (c,d) Manhattan plots showing association test results for variants on the opposite haplotype of deleterious variants in FLG and CFTR with asthma (the phenotype most strongly associated with carrier status in each case). No association reached Bonferroni significance (red line). (e,f) Power analyses for the tests conducted in c,d indicate that these tests were well-powered to detect common variant effects with odds ratios $>1.2$.

a

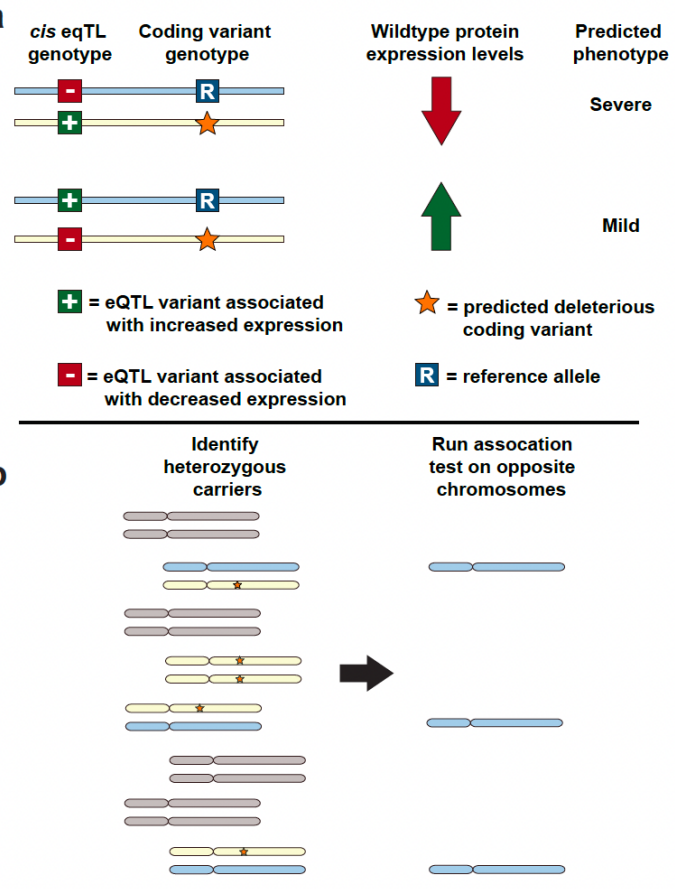

C
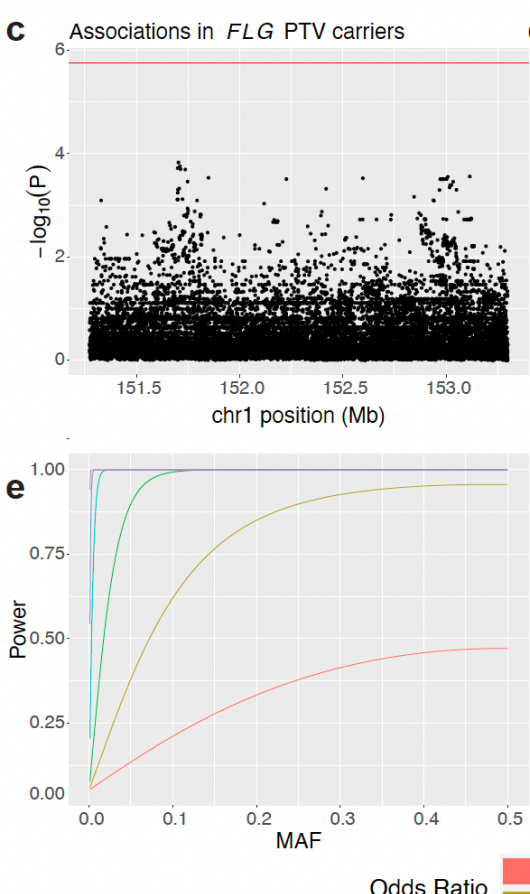

d Associations in CFTR Phe508del carriers
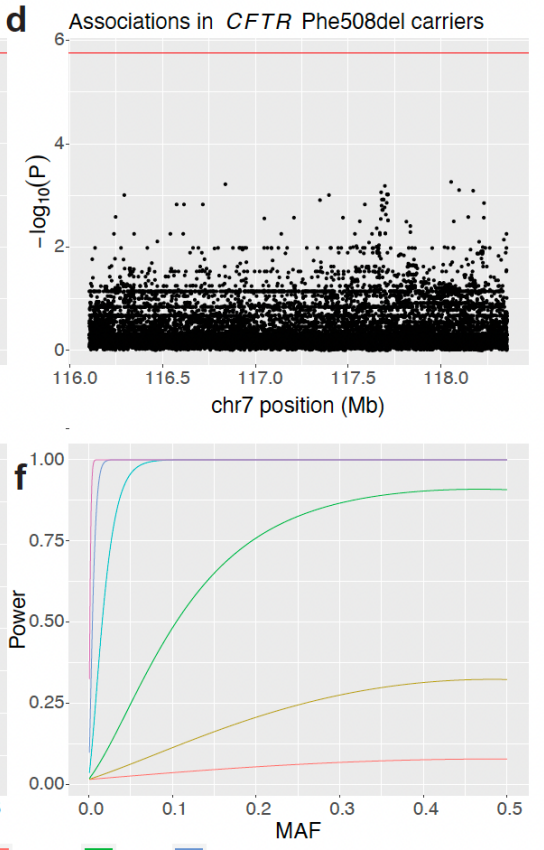

1.2

3 
medRxiv preprint doi: https://doi.org/10.1101/2021.12.13.21267756; this version posted December 14, 2021. The copyright holder for this preprint (which was not certified by peer review) is the author/funder, who has granted medRxiv a license to display the preprint in perpetuity.

\section{Tables}

Table 1. Carriers of Mendelian recessive disease variants exhibit increased risk of less-severe disease phenotypes. Odds ratios and $p$-values are reported for the five associations that reached

\begin{tabular}{|c|c|c|c|c|c|c|c|c|}
\hline \multirow{2}{*}{$\begin{array}{l}\text { Recessive } \\
\text { disease } \\
\text { association }\end{array}$} & \multicolumn{4}{|c|}{ ClinVar reported variant } & \multirow{2}{*}{$\begin{array}{l}\text { Disease } \\
\text { association in } \\
\text { carriers }\end{array}$} & \multirow[b]{2}{*}{ Trait category } & \multirow[b]{2}{*}{ OR (95\% Cl) } & \multirow[b]{2}{*}{ P-Value } \\
\hline & Gene & Variant & $\begin{array}{l}\text { Variant } \\
\text { impact }\end{array}$ & MAF & & & & \\
\hline $\begin{array}{l}\text { Alport } \\
\text { syndrome } 2\end{array}$ & COL4A4 & 2:227917083:G:C & $\begin{array}{l}\text { stop } \\
\text { gained }\end{array}$ & 6.16E-04 & $\begin{array}{l}\text { Recurrent and } \\
\text { persistent } \\
\text { haematuria (N02) }\end{array}$ & $\begin{array}{l}\text { Genitourinary } \\
\text { system } \\
\text { disorders }\end{array}$ & $\begin{array}{l}10.47(5.17- \\
21.2)\end{array}$ & $6.75 \mathrm{E}-11$ \\
\hline $\begin{array}{l}\text { Thyroid } \\
\text { dyshormono- } \\
\text { genesis } 3\end{array}$ & $T G$ & 8:133894854:C:T & $\begin{array}{l}\text { stop } \\
\text { gained }\end{array}$ & $6.38 \mathrm{E}-04$ & $\begin{array}{l}\text { Other } \\
\text { hypothyroidism } \\
\text { (E03) }\end{array}$ & $\begin{array}{l}\text { Endocrine, } \\
\text { nutritional and } \\
\text { metabolic } \\
\text { diseases }\end{array}$ & $\begin{array}{l}2.20(1.68- \\
2.88)\end{array}$ & $9.72 \mathrm{E}-09$ \\
\hline $\begin{array}{l}\text { Sickle cell } \\
\text { anemia }\end{array}$ & $H B B$ & 11:5248233:CAG:C & frameshift & 2.15E-05 & $\begin{array}{l}\text { Thalassaemia } \\
\text { (D56) }\end{array}$ & $\begin{array}{l}\text { Blood, blood- } \\
\text { forming organs } \\
\text { and certain } \\
\text { immune } \\
\text { disorders }\end{array}$ & $\begin{array}{l}3,183(440- \\
23,030)\end{array}$ & $1.36 \mathrm{E}-15$ \\
\hline $\begin{array}{l}\text { Albinism, } \\
\text { oculo- } \\
\text { cutaneous, } \\
\text { type IA }\end{array}$ & $T Y R$ & 11:88961072:C:A & missense & 1.10E-03 & $\begin{array}{l}\text { Disorders of } \\
\text { aromatic amino- } \\
\text { acid metabolism } \\
\text { (E70) }\end{array}$ & $\begin{array}{l}\text { Endocrine, } \\
\text { nutritional and } \\
\text { metabolic } \\
\text { diseases }\end{array}$ & $\begin{array}{l}63.27(16.33- \\
245.10)\end{array}$ & 1.94E-09 \\
\hline $\begin{array}{l}\text { Retinitis } \\
\text { pigmentosa } \\
80 \text { \& short rib } \\
\text { thoracic } \\
\text { dysplasia } 9\end{array}$ & IFT140 & 16:1607935:C:A & $\begin{array}{l}\text { splice } \\
\text { donor }\end{array}$ & 5.11E-04 & $\begin{array}{l}\text { Cystic kidney } \\
\text { disease (Q61) }\end{array}$ & $\begin{array}{l}\text { Congenital } \\
\text { disruptions and } \\
\text { chromosomal } \\
\text { abnormalities }\end{array}$ & $\begin{array}{l}18.42(8.47- \\
40.05)\end{array}$ & $1.98 \mathrm{E}-13$ \\
\hline
\end{tabular}

